\title{
SEMINAL DEGENERATION IN THE RAM AND ITS RELATION TO THE TEMPERATURE OF THE SCROTUM
}

\author{
G. R. MOULE AND G. M. H. WAITES \\ C.S.I.R.O., Division of Animal Physiology, The Ian Clunies Ross \\ Animal Research Laboratory, Prospect, N.S.W., Australia*
}

(Received 4th December 1962)

\begin{abstract}
Summary. The semen collected from twelve Merino rams was examined before and after they were exposed during 3 days to two 6-hr periods in a climate room at $40.5^{\circ} \mathrm{C}, 8.5 \mathrm{~mm} \mathrm{Hg}$ vapour pressure and $40.5^{\circ} \mathrm{C}, 31.5 \mathrm{~mm} \mathrm{Hg}$, respectively. Semen of decreased quality was collected from all the rams after this treatment. The change varied markedly in severity and duration and was related to the rise of the temperature of the subcutaneous tissue of the scrotum measured during the climate-room treatment and not to changes in rectal or flank-skin temperatures. The first ejaculate containing abnormal spermatozoa was collected 13 to 21 days after the treatment, and the concentration and total content of fructose in the semen of all rams started to rise at this time. The three rams which were most severely affected suffered a seminal degeneration which lasted for 35 to 39 days.

After recovery from the first experiment, the same rams were divided into three groups of four. Two groups were exposed to the same heat treatments as before and the third group stood in the climate room for $12 \mathrm{hr}$ at $21^{\circ} \mathrm{C}$ and $6.8 \mathrm{~mm} \mathrm{Hg}$ vapour pressure. Water at 17 to $19^{\circ} \mathrm{C}$ was circulated around the scrotum of one group of rams exposed to heat and of the group in the thermo-neutral environment. Only the rams exposed to heat without their scrota cooled in this way produced semen of inferior quality. It was concluded that under the conditions of these experiments, the efficiency of the heat-dissipating properties of the scrotum alone decided the magnitude of the adverse effects of short periods of raised air temperature on the quality of the semen produced by Merino rams.
\end{abstract}

\section{INTRODUGTION}

The exposure of rams to high ambient air temperature is usually followed by seminal degeneration, the intensity of which varies between breeds of sheep and between rams of the same breed (McKenzie \& Berliner, 1937; Gunn, Sanders \& Granger, 1942). Similar effects may be produced by insulating the scrotum

\footnotetext{
* Postal address: The Ian Clunies Ross Animal Research Laboratory, C.S.I.R.O., P.O. Box 144, Parramatta, N.S.W., Australia.
} 
to prevent heat loss (Moore \& Oslund, 1924; Gunn, 1936; Glover, 1955). The seminal degeneration that follows exposure of rams to high air temperatures appears to be due to the direct effects of heat on the testis, for when temperature stress is severe, local thermo-regulation fails and testicular temperatures rise (Moule \& Knapp, 1950). However, it is not possible from previous experiments to distinguish between the effects that high testicular temperature may have on spermatogenesis and other reactions of rams to high air temperatures which might indirectly influence testicular function.

The present experiments were designed to examine three points. Firstly, to determine the effects of short periods of heat stress on the semen production of individual rams of the same breed. Secondly, to attempt to relate the ability of individual rams to regulate testicular temperatures during exposure to high environmental air temperatures to the ensuing changes in semen quality. Thirdly, to establish if semen quality was affected by a similar heat stress applied to animals whose scrota were kept cool.

\section{MATERIALS AND METHODS}

Sixteen 3-year-old Peppin strain Merino rams were used. They were shorn in October 1959 and the observations reported here were made during the ensuing autumn, winter and spring. The rams were kept in a well-ventilated shed subject to adequate natural illumination. They were treated to remove worms and were given lucerne chaff and water ad libitum. Every 12 weeks they were given 500,000 i.u. of vitamins A and D.

\section{Semen collection}

Semen samples were obtained by electrical stimulation with a bipolar electrode (Blackshaw, 1954) inserted into the rectum. The volume of each sample was recorded and a small portion was immediately deep-frozen for subsequent estimation of fructose content (Mann, 1948).

\section{Semen evaluation}

A drop of semen was examined on a cavity slide on a warmed microscope stage within 2 min of collection. The speed and frequency of the mass movements of the spermatozoa were assessed at low magnification and scored from 0 to 5 . The proportion of actively progressing spermatozoa was assessed at high magnification and scored from 0 to 5 , with 5 indicating maximum activity. The percentages of live and of morphologically normal spermatozoa were determined from smears stained supravitally with nigrosin and cosin (Hancock, 1952). Spermatozoa that were tailless, or had coiled tails, protoplasmic droplets on the tail, or pyriform heads were classified as abnormal. To aid in comparing ejaculates, each $10 \%$ of live, and each $10 \%$ of morphologically normal spermatozoa in the sample were given one point, and these were added to the scores for wave motion and active spermatozoa to give a composite score with a possible maximum of 30 for any sample. The composite scores of all ejaculates collected from individual rams during the pretreatment period did not vary by more than $25 \%$ of the mean. Thus, ejaculates collected during the post-treat- 
ment period were considered to be of inferior quality if their composite score was less than $75 \%$ of the pretreatment mean.

The concentration of spermatozoa was measured turbidometrically (Comstock, Green, Winters \& Nordskog, 1943) with $0.9 \% \mathrm{NaCl}$ as a diluent. The results were checked periodically by direct counting with a haemocytometer. For reasons outlined by Mattner \& Voglmayr (1962), a decrease in the concentration of spermatozoa was considered to be significant only if it occurred in successive samples, and was associated with a corresponding change in other characters.

\section{Temperature measurement}

Tissue temperatures were measured with 38 s.w.g. copper-constantan thermocouples mounted in hypodermic needles (21 and 22 s.w.g.) and recorded by a potentiometric recorder (Leeds and Northrup Type G, Model S; $1 \mathrm{mV}$ full-scale deflection). Rectal temperatures were taken with a clinical thermometer or with a thermocouple mounted in a polythene probe. Wet and dry bulb air temperatures in the climate room were recorded with a whirling psychrometer and an Assmann thermometer.

\section{Experiment 1}

EXPERIMENTAL DESIGN

Five to seven ejaculates were collected from each of fourteen rams at regular intervals during the 31 days preceding entry into the climate room; three were obtained from each ram in the last 12 days. Twelve of the rams were exposed in a climate room to two periods each of $6 \mathrm{hr} \pm 5 \mathrm{~min}$ to the following conditions: $40.5^{\circ} \mathrm{C}$ (dry bulb), $8.5 \mathrm{~mm} \mathrm{Hg}$ vapour pressure; $40.5^{\circ} \mathrm{C}$ (dry bulb), $31.5 \mathrm{~mm}$ $\mathrm{Hg} ; 42 \mathrm{hr}$ separated the two periods. As only six rams could be accommodated at one time, treatments were spread over the 4 days, May 9th to 12th, 1960. The rams were moved to an ante-room for $1 \mathrm{hr}$ before entering the climate room. The respiratory rates, rectal temperatures and the subcutaneous temperatures from the flank, mid-anterior and mid-posterior regions of the scrotum of each ram were recorded in the ante-room at 1,3 and $6 \mathrm{hr}$ after entering the climate room. Similar records were obtained from two control rams held in the climate room on other days for two 6-hr periods at $22^{\circ} \mathrm{C}$ (dry bulb) and $6.5 \mathrm{~mm}$ $\mathrm{Hg}$ vapour pressure. A semen sample was collected from all rams $24 \mathrm{hr}$ after leaving the climate room. Ejaculates were collected twice weekly from the experimental rams and at weekly intervals from the control rams for the next 9 weeks. For the purpose of analysis, subsequent changes in semen characters were related to the date of the first treatment in the climate room, called Day 1.

\section{Experiment 2}

The twelve experimental rams were divided into three groups of four; one severely affected ram (Table 1) was put into each group and the rest were allotted randomly. Long wool was removed from the scrotum of each ram to leave a short uniform covering. Semen samples were collected and evaluated twice weekly for 3 weeks before, and 12 weeks after the experimental treatments, which were completed between 22nd and 26th August, 1960. Groups 1 and 2 
were put into the climate room for $6 \mathrm{hr} \pm 8 \mathrm{~min}$ on two occasions at $40 \cdot 5^{\circ} \mathrm{C}$ (dry bulb) and $8.5 \mathrm{~mm} \mathrm{Hg}$ vapour pressure and $40.5^{\circ} \mathrm{C}$ (dry bulb) and $31.5 \mathrm{~mm}$ $\mathrm{Hg}$, respectively, as in Experiment 1. The control rams of Group 3 were held for two 6-hr periods in the climate room in air temperatures of $21^{\circ} \mathrm{C}$ (dry bulb) and $6.8 \mathrm{~mm} \mathrm{Hg}$ vapour pressure. The rams of Groups 2 and 3 carried a polythene cylinder that enclosed the scrotum, and water at 17 to $19^{\circ} \mathrm{C}$ circulated between the scrotum and cylinder for each of the 6-hr periods. Respiratory rates and rectal temperatures were recorded in the ante-room and at 1, 3 and $6 \mathrm{hr}$ after entering the climate room.

The temperatures in the rectum, deep in the testis and in the subcutaneous tissue of the scrotum were recorded from two other rams that were in the climate room with Groups 1 and 2. They were used only as test rams to indicate the changes in temperature of the testis and scrotum with and without scrotal cooling; semen was not collected from them.

\section{RESULTS}

\section{Changes in semen characters}

\section{EXPERIMENT 1}

None of the ejaculates collected from the control rams, before or after they were confined for $12 \mathrm{hr}$ in the climate room at $22^{\circ} \mathrm{C}$ (dry bulb) and $6.5 \mathrm{~mm}$ $\mathrm{Hg}$ vapour pressure, received a score below $75 \%$ of the pretreatment mean although the concentration of spermatozoa fell below $1500 \mathrm{million} / \mathrm{ml}$ in one ejaculate from each ram. After exposure to high air temperatures, each experimental ram exhibited a deterioration in semen quality which, in some individuals, was severe enough to be regarded as a degeneration. This is illustrated for three rams in Text-fig. 1; every ejaculate collected from Ram 74 between Days 13 to 52, five from Ram 60 during Days 21 to 49, and one from Ram 69 on Day 20 were of inferior quality. Accepting that damage can be inferred only if at least two inferior ejaculates were collected successively (Anderson, 1945), each ram was assigned arbitrarily to one of three classes according to the number and frequency of inferior ejaculates collected following the climate room treatment (Table 1):

Class A-Three rams with well-defined seminal degeneration lasting 35 to 39 days;

Class B-Four rams with milder seminal degeneration, each producing at least three successive ejaculates of inferior quality;

Class C-Five rams, from each of which only one or two samples of inferior quality were collected. No seminal degeneration was ascribed to these rams as individuals, but as a group, the number of normal spermatozoa in their semen was markedly reduced in three successive samples collected during the period, Days 16 to 25 (Text-fig. 2(a)).

The mean percentage of normal and of live spermatozoa in the semen of the Class A rams, i.e. those most severely affected, began to decrease on Day 13 or 14. In the semen of the rams of Classes $B$ and $G$ this change occurred between Days 14 to 21 (Text-fig. 2(a) and (b)). Tailless spermatozoa always stained 
with eosin, and were thus defined as dead (Hancock, 1952), whereas the spermatozoa with coiled tails frequently remained unstained and were therefore classified as live. Loss and coiling of tails were the two morphological abnormalities most often observed. No semen sample collected from the experimental rams during the pretreatment period, or from the two control rams throughout the experimental period, contained more than $15 \%$ of tailless spermatozoa or more than $30 \%$ with coiled tails. Between six and nine ejaculates collected from each of the Class A rams after exposure to high air temperatures, contained more than $15 \%$ tailless spermatozoa or $30 \%$ with coiled tails (Table 1 ). Fewer ejaculates containing increased numbers of abnormal spermatozoa were collected from the Class $\mathrm{B}$ and $\mathrm{C}$ rams during the same period.

The concentration of spermatozoa in the semen of the Class A rams declined

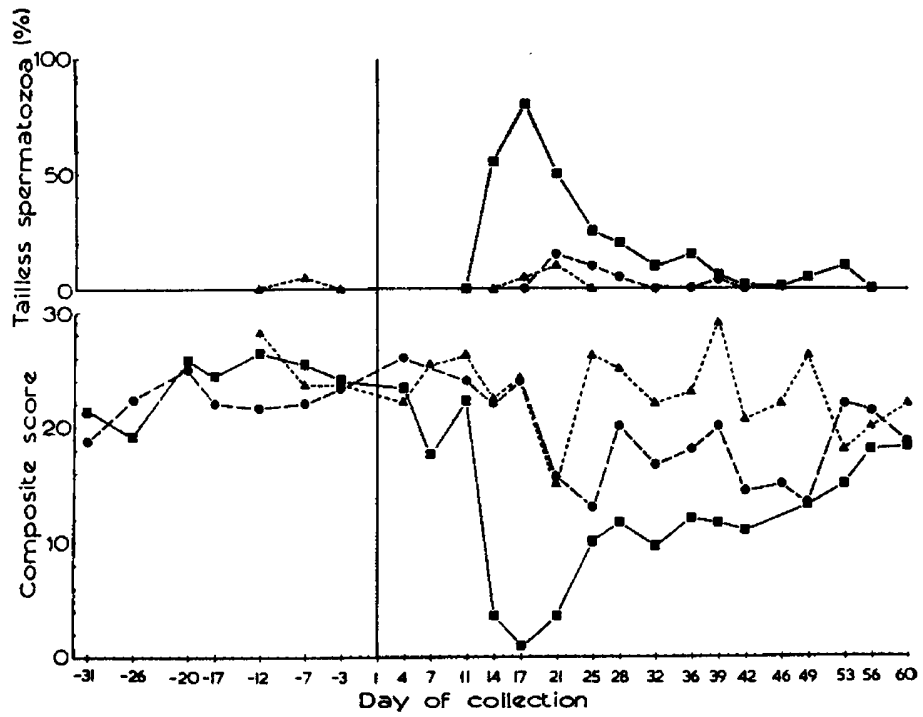

TEXT-FIG. 1. Semen characters of three rams before and after exposure to two 6-hr periods of raised air temperature. Each ram was representative of the three classes defined in Table $1 . \mathbf{0}=\operatorname{Ram} 74 ; 0=\operatorname{Ram} 60 ; \Delta=\operatorname{Ram} 69$.

on Day 14 and remained below 1500 million/ml for all three rams between Days 21 to 32 ; during this period, spermatozoa were almost completely absent from one to four ejaculates from each ram (Text-fig. 2 (c)). The concentration of spermatozoa in the semen of these rams remained below the pretreatment range until Day 60, the last collection day for Experiment 1, but had risen into the range 2600 to 3700 million/ml by Day 85, the first collection day of Experiment 2. Sperm concentration in the semen of all the other rams was not consistently lowered during the post-treatment period.

The concentration, and the total amounts of fructose in the ejaculates of all the experimental rams increased after treatment. The mean fructose concentration for each class rose from Days 16 to 17 onwards, to well above the range 1.0 to $2.0 \mathrm{mg} / \mathrm{ml}$ observed during the pretreatment period. It reached a maximum of almost $9.0 \mathrm{mg} / \mathrm{ml}$ on Days 37 to 38 in the semen collected from the 
Class A rams. Maxima of 4.3 and $7.0 \mathrm{mg} / \mathrm{ml}$ were recorded for the rams of the other classes on Days 53 to 54 . However, because of differences between the volumes of semen produced, the total amounts of fructose showed even greater fluctuations (Text-fig. 3).

\section{Relationship of seminal damage to thermal responses}

The seminal degeneration exhibited by individual rams was assessed by subtracting the mean of the composite scores for their respective ejaculates collected between Days 13 to 52 (the longest period of seminal degeneration, Ram 74, Table 1) from the mean score of the pretreatment ejaculates (Table 2).

TABLE 1

SEMINAL DEGENERATION EXPERIENGED BY TWELVE RAMS FOLLOWING EXPOSURE FOR 12 HR TO RAISED AIR TEMPERATURE

\begin{tabular}{|c|c|c|c|c|c|c|c|c|c|}
\hline \multirow{4}{*}{$\underset{\mathcal{N}}{R a}$} & & \multicolumn{8}{|c|}{ Ejaculates $<75 \%$ of pretreatment composite score $*$} \\
\hline & & \multicolumn{4}{|c|}{ Days $\uparrow$} & \multicolumn{4}{|c|}{ No. exhibiting } \\
\hline & & \multirow{2}{*}{ Total } & \multicolumn{2}{|c|}{ Appearance } & \multirow{2}{*}{ Duration } & \multirow{2}{*}{$\begin{array}{c}\text { No } \\
\text { wave } \\
\text { motion }\end{array}$} & \multirow{2}{*}{$\begin{array}{l}>50 \% \\
\text { Dead } \\
\text { sperm- } \\
\text { atozoa }\end{array}$} & \multirow{2}{*}{$\begin{array}{l}\geq 15 \% \\
\text { Tailless } \\
\text { sperm- } \\
\text { atozoa }\end{array}$} & \multirow{2}{*}{$\begin{array}{c}>30 \% \\
\text { Coiled } \\
\text { tails }\end{array}$} \\
\hline & & & First & Last & & & & & \\
\hline Class A & $\begin{array}{l}74 \\
68 \\
72\end{array}$ & $\begin{array}{l}12 \\
11 \\
11\end{array}$ & $\begin{array}{l}13 \\
14 \\
13\end{array}$ & $\begin{array}{l}52 \\
49 \\
48\end{array}$ & $\begin{array}{l}39 \\
35 \\
35\end{array}$ & $\begin{array}{l}12 \\
11 \\
10\end{array}$ & $\begin{array}{l}7 \\
9 \\
8\end{array}$ & $\begin{array}{l}6 \\
9 \\
9\end{array}$ & $\begin{array}{l}6 \\
1 \\
7\end{array}$ \\
\hline Class B & $\begin{array}{l}65 \\
60 \\
56 \\
55\end{array}$ & $\begin{array}{l}5 \\
5 \\
4 \\
4\end{array}$ & $\begin{array}{l}17 \\
21 \\
14 \\
17\end{array}$ & $\begin{array}{l}39 \\
49 \\
28 \\
36\end{array}$ & $\begin{array}{l}20 \\
20 \\
16 \\
16\end{array}$ & $\begin{array}{l}5 \\
3 \\
1 \\
2\end{array}$ & $\begin{array}{l}5 \\
4 \\
2 \\
2\end{array}$ & $\begin{array}{l}5 \\
0 \\
3 \\
2\end{array}$ & $\begin{array}{l}0 \\
1 \\
0 \\
3\end{array}$ \\
\hline Class $\mathrm{C}$ & $\begin{array}{l}64 \\
75 \\
71 \\
70 \\
69\end{array}$ & $\begin{array}{l}2 \\
2 \\
2 \\
2 \\
1\end{array}$ & $\begin{array}{l}17 \\
16 \\
20 \\
20 \\
20\end{array}$ & $\begin{array}{c}21 \\
24 \\
31 \\
52 \\
-\end{array}$ & $\begin{array}{l}8 \\
8 \\
8 \\
8 \\
4\end{array}$ & $\begin{array}{l}0 \\
2 \\
0 \\
0 \\
0\end{array}$ & $\begin{array}{l}0 \\
0 \\
0 \\
2 \\
0\end{array}$ & $\begin{array}{l}2 \\
2 \\
0 \\
1 \\
0\end{array}$ & $\begin{array}{l}0 \\
0 \\
3 \\
0 \\
0\end{array}$ \\
\hline
\end{tabular}

* Composite score is composed equally of 1 point given for each $10 \%$ live, for each $10 \%$ morphologically normal and for each of ten grades of activity for the spermatozoa in each semen sample.

$\dagger$ Day on which first and last ejaculates of inferior quality were collected; days numbered from day of first climate-room treatment.

I Total of seventeen ejaculates collected from each ram in sixty post-treatment days.

Scores that slightly exceeded the pretreatment mean were considered as being equal to it, as these minor fluctuations appear to have little biological significance. On both occasions the temperature of the deep scrotal tissues derived from the mean of the anterior and posterior readings rose quickly during the lst $\mathrm{hr}$ in the climate room, and then more gradually until the 6th $\mathrm{hr}$. Scrotal temperatures of the Class A rams were close to their respective rectal temperatures at the end of the first 6-hr period in the climate room, whereas a rectal-scrotal gradient of 1.6 to $3.2^{\circ} \mathrm{C}$ remained in the Class $\mathrm{C}$ rams (Table 2; Text-fig. 4(a)). During the second treatment in the climate room, scrotal temperatures of all rams rose to a higher level, although at all stages the mean 
and the range of temperatures recorded from the Class $\mathrm{A}$ rams were higher than those from the B and $\mathrm{C}$ class rams (Table 2; Text-fig. 4(b)).

The scores for semen damage for each ram were plotted against the highest temperature recorded from the scrotum during the climate-room treatments and the relationship shown in Text-fig. 5 was obtained. No relationship was found between seminal degeneration and the changes in rectal, or flank temp-

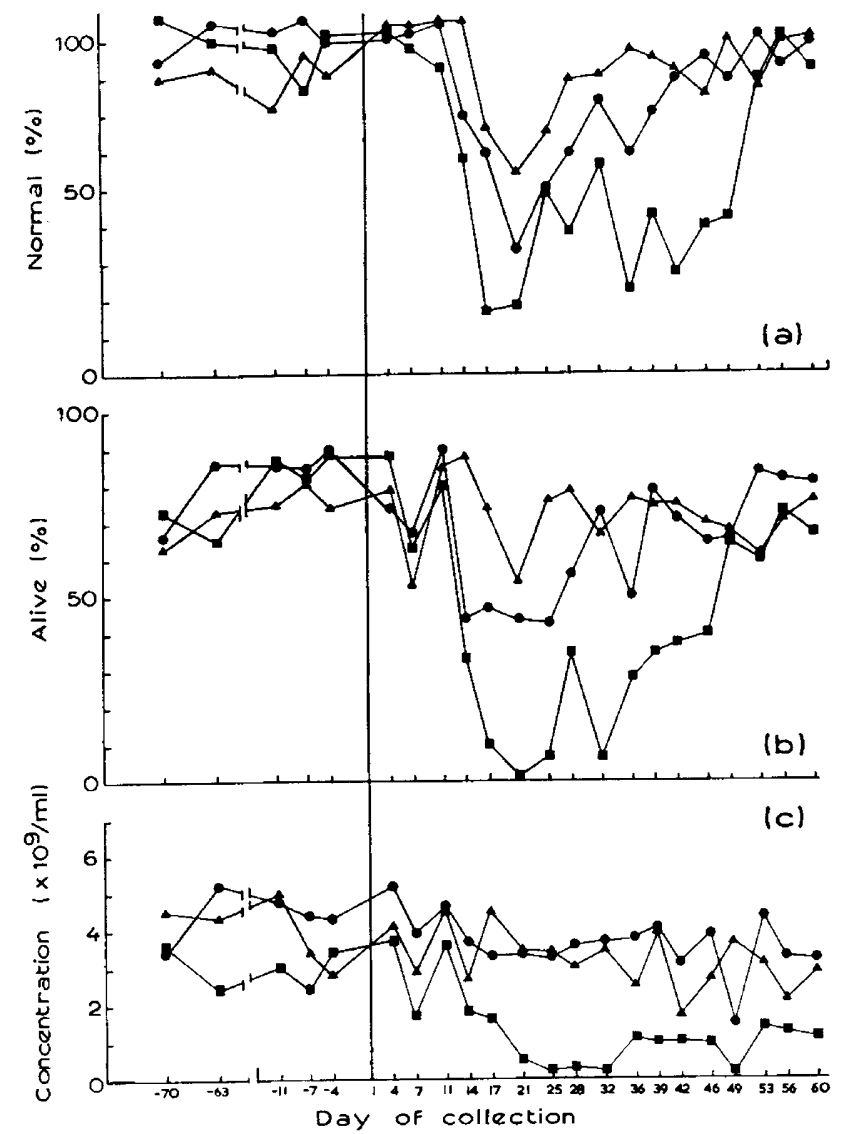

Text-Fig. 2. The mean percentage of (a) morphologically normal and (b) live spermatozoa, and (c) the concentration of spermatozoa, in the semen of the Class $A$ (a), Class B (O) and Class C (A) rams during Experiment 1.

eratures, or the increases in respiratory rates recorded during either of the climate-room treatments.

Changes in semen quality

EXPERIMENT 2

All the rams whose scrota were unprotected by cooling (Group 1) produced semen of markedly reduced quality between Days 18 to 25, although the proportion of tailless spermatozoa had already increased in the ejaculates collected on Day 15 (Text-fig. 6). The lowest numbers of live spermatozoa and 
the lowest scores for motility were recorded on Day 18 . No trends that could be attributed to treatments were observed in the concentration of spermatozoa. The semen produced by the rams whose scrota were cooled (Groups 2 and 3) remained unchanged.

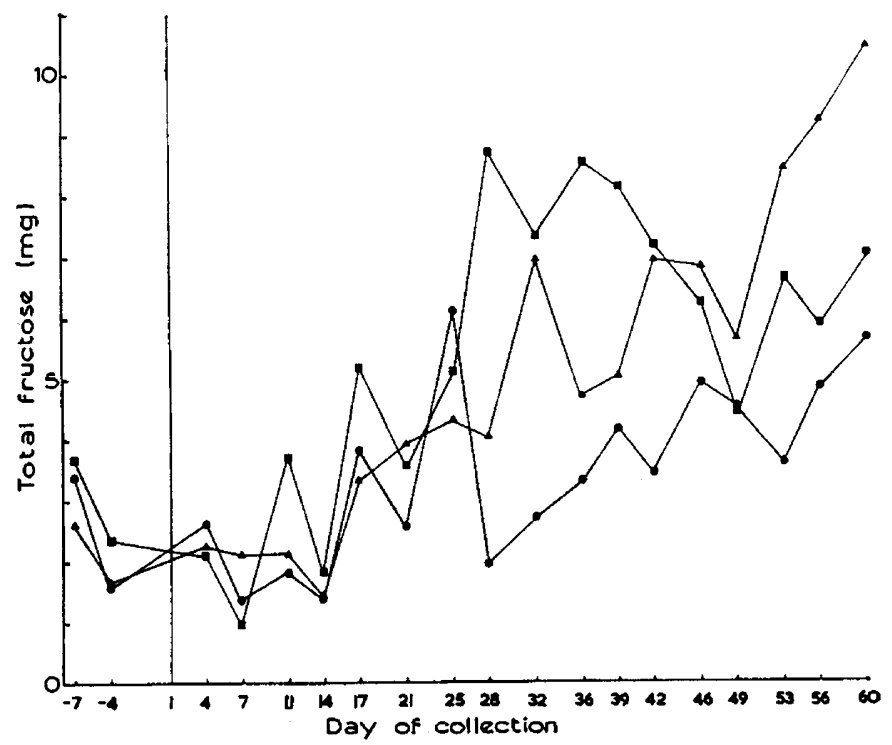

Text-Fig. 3. The mean values for the total fructose content of the semen of the three classes of rams during Experiment 1 (Symbols as in Text-fig. 2).
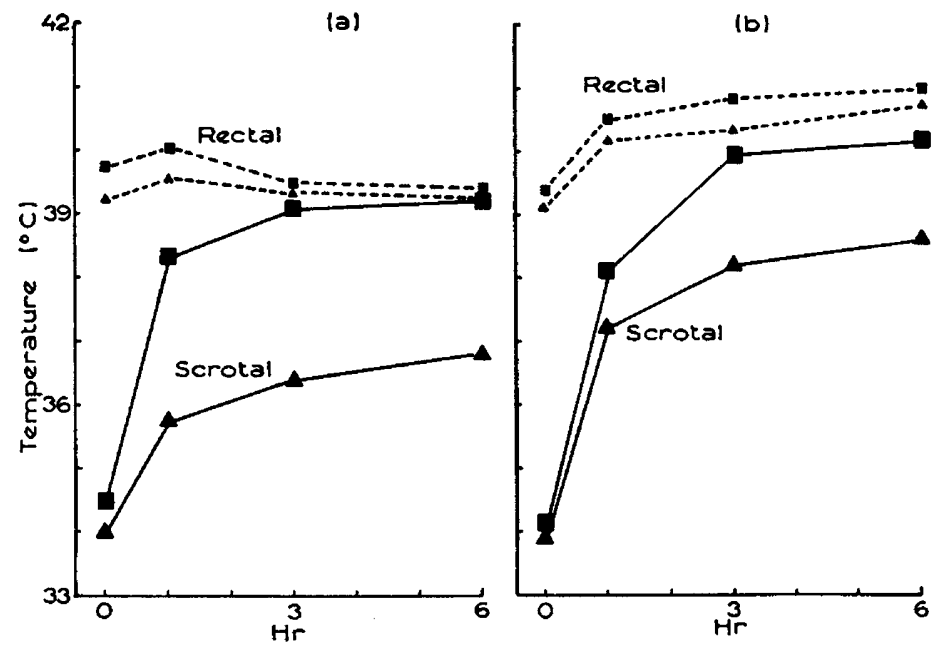

Text-Fig. 4. The mean rectal and subcutaneous scrotal temperatures of the rams of Class A ( $\mathbf{a})$ and Class $\mathrm{C}(\boldsymbol{\Lambda})$ during the two periods of raised air temperature $\left[(\mathrm{a}) 40.5^{\circ} \mathrm{C}\right.$ (dry bulb), $8.5 \mathrm{~mm} \mathrm{Hg} \mathrm{H} \mathrm{m}_{2} \mathrm{O}$ vapour; (b) $40.5^{\circ} \mathrm{C}$ (dry bulb), $31.5 \mathrm{~mm} \mathrm{Hg} \mathrm{H}_{2} \mathrm{O}$ vapour].

The concentration of seminal fructose of all rams was unaffected by the treatments. However, owing to an increase in the volume of the ejaculates collected from the rams of Group 1 on Day 15, there was an increase of from 7 
to $19 \mathrm{mg}$ in the mean total content of fructose which, with the exception of one collection, was maintained until Day 43. By Day 47, it had returned to the pretreatment levels.

\section{TABLE 2}

SUBCUTANEOUS SCROTAL AND REGTAL TEMPERATURES OF EACH RAM AFTER 6 HR EXPOSURE TO HOT DRY AND HOT HUMID CONDITIONS RESPECTIVELY AND THEIR SCORES OF SEMEN DAMAGE

\begin{tabular}{|c|c|c|c|c|c|c|}
\hline \multirow{2}{*}{\multicolumn{2}{|c|}{$\begin{array}{c}\text { Ram } \\
\text { No. }\end{array}$}} & \multicolumn{2}{|c|}{$\begin{array}{c}\text { Period } 1 \\
40.5^{\circ} \mathrm{C} \text { and } 8.5 \mathrm{~mm} \mathrm{Hg} \\
\text { vapour pressure }\end{array}$} & \multicolumn{2}{|c|}{$\begin{array}{c}\text { Period } 2 \\
40-5^{\circ} \mathrm{C} \text { and } 31.5 \mathrm{~mm} \mathrm{Hg} \\
\text { vapour pressure }\end{array}$} & \multirow{2}{*}{$\begin{array}{c}\text { Score for semen damage } \\
\text { (mean pretreatment score } \\
- \text { mean score between Days } \\
13 \text { and } 52)\end{array}$} \\
\hline & & $\begin{array}{c}\text { Subcutaneous } \\
\text { scrotal }\end{array}$ & Rectal & $\begin{array}{c}\text { Subcutaneous } \\
\text { scrotal }\end{array}$ & Rectal & \\
\hline Class A & $\begin{array}{l}68 \\
74 \\
72\end{array}$ & $\begin{array}{l}39 \cdot 3 \\
39 \cdot 6 \\
39 \cdot 0\end{array}$ & $\begin{array}{l}39 \cdot 4 \\
39 \cdot 5 \\
39 \cdot 1\end{array}$ & $\begin{array}{l}40 \cdot 4 \\
40 \cdot 5 \\
40 \cdot 0\end{array}$ & $\begin{array}{l}41 \cdot 1 \\
41 \cdot 3 \\
40 \cdot 9\end{array}$ & $\begin{array}{l}15 \cdot 3 \\
14 \cdot 5 \\
14 \cdot 4\end{array}$ \\
\hline Class B & $\begin{array}{l}65 \\
56 \\
55 \\
60\end{array}$ & $\begin{array}{l}38 \cdot 2 \\
38 \cdot 4 \\
37 \cdot 4 \\
37 \cdot 5\end{array}$ & $\begin{array}{l}39 \cdot 7 \\
39 \cdot 4 \\
40 \cdot 2 \\
39 \cdot 7\end{array}$ & $\begin{array}{l}39 \cdot 8 \\
39 \cdot 8 \\
39 \cdot 6 \\
39 \cdot 3\end{array}$ & $\begin{array}{l}41 \cdot 6 \\
41 \cdot 4 \\
41 \cdot 7 \\
40 \cdot 8\end{array}$ & $\begin{array}{r}12 \cdot 0 \\
5 \cdot 5 \\
5 \cdot 5 \\
4 \cdot 4\end{array}$ \\
\hline Class C & $\begin{array}{l}64 \\
71 \\
75 \\
70 \\
69\end{array}$ & $\begin{array}{l}37 \cdot 2 \\
37 \cdot 4 \\
37 \cdot 8 \\
35 \cdot 6 \\
36 \cdot 3\end{array}$ & $\begin{array}{l}39 \cdot 3 \\
39 \cdot 7 \\
39 \cdot 4 \\
38 \cdot 8 \\
39 \cdot 4\end{array}$ & $\begin{array}{l}39 \cdot 2 \\
38 \cdot 6 \\
39 \cdot 3 \\
38 \cdot 0 \\
38 \cdot 6\end{array}$ & $\begin{array}{l}40 \cdot 7 \\
40 \cdot 8 \\
41 \cdot 3 \\
40 \cdot 6 \\
41 \cdot 1\end{array}$ & $\begin{array}{l}4 \cdot 2 \\
3 \cdot 8 \\
3 \cdot 5 \\
3 \cdot 5 \\
2 \cdot 8\end{array}$ \\
\hline
\end{tabular}

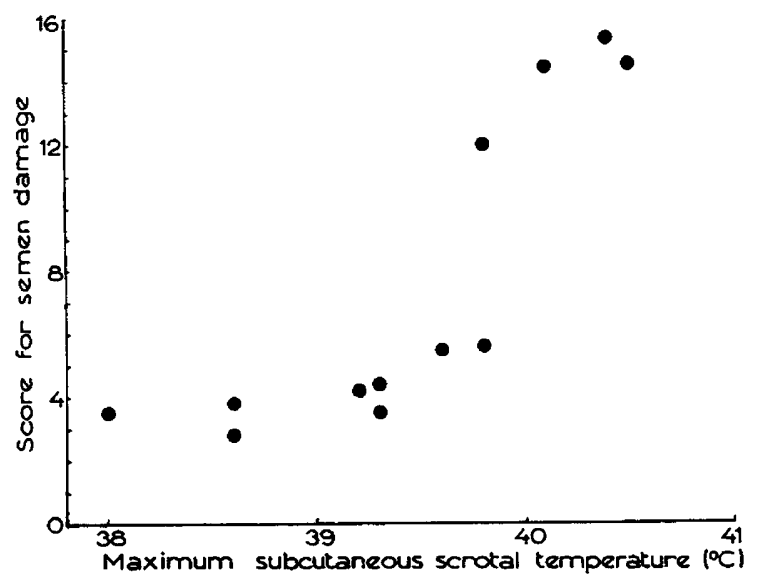

TEXT-FIG. 5. The relationship between scores for semen damage and the highest temperature recorded from the scrota of the rams during the climate-room treatments. Scrotal temperatures plotted are the mean of two subcutaneous temperatures recorded during Period 2 in the climate room (see Table 2).

\section{Scrotal and testicular temperature}

The circulation of water at 17 to $19^{\circ} \mathrm{C}$ around the scrotum of one test ram caused the temperatures of the subcutaneous scrotal tissue and of the testis to fall rapidly during the $1 \mathrm{st} \mathrm{hr}$, and for the remaining $5 \mathrm{hr}$ they remained between 
26 and $31^{\circ} \mathrm{C}$, i.e. 9 to $14^{\circ} \mathrm{C}$ below rectal temperatures (Text-fig. 7). By contrast, in the ram without scrotal cooling the rectal-testicular difference was $1.5^{\circ} \mathrm{C}$ at the end of both periods; both temperatures were lower during the hot dry conditions (Text-fig. 7).

Rams with scrota protected by cooling and those with unprotected scrota did not differ appreciably in respiratory rates or rectal temperatures during the treatments.

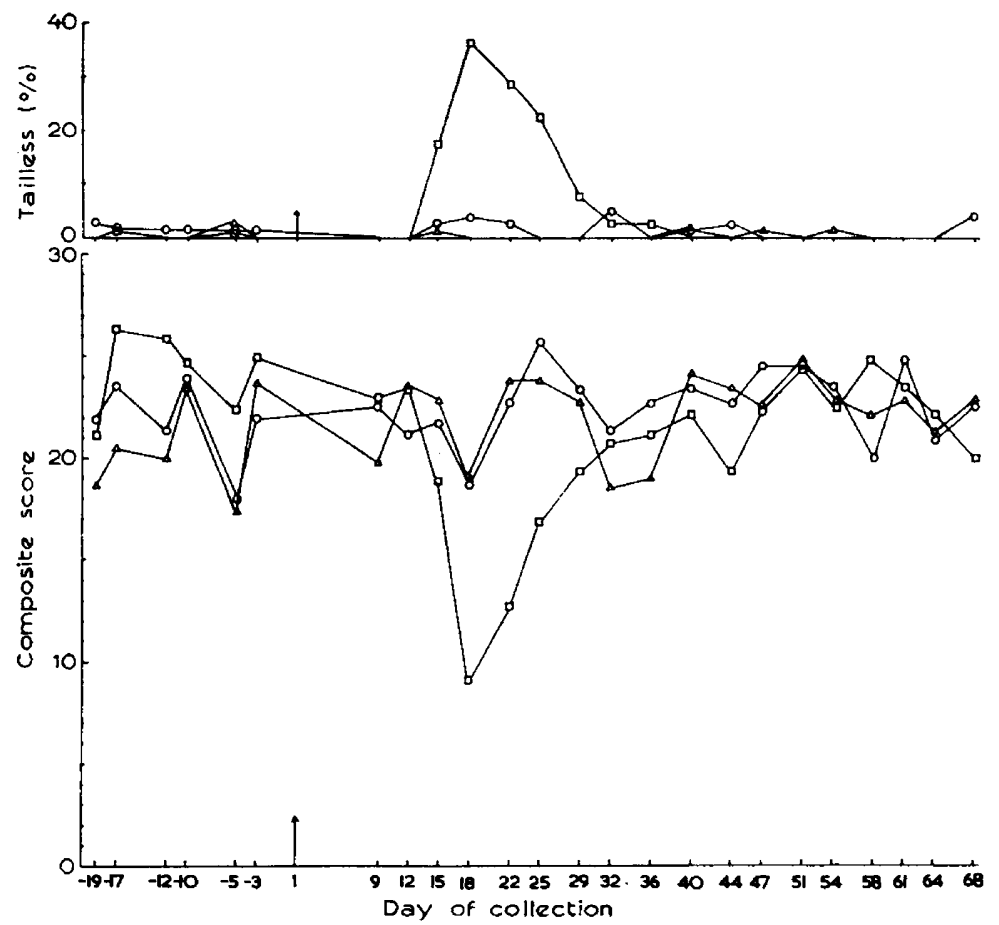

TEXT-FIG. 6. The mean composite scores (below) and mean percentage of tailless spermatozoa (above) of the ejaculates from the three groups of rams in Experiment 2.

Groups 1 and 2 in climate room at $40 \cdot 5^{\circ} \mathrm{C}$ (dry bulb): Unprotected scrotum $=\square$; cooled scrotum $=0$.

Group 3 in climate room at $21^{\circ} \mathrm{C}$ (dry bulb): Cooled scrotum $=\Delta$.

Day 1 = first day of experimental treatment.

\section{DISCUSSION}

The present experiments confirm the findings of Gunn et al. (1942) and McKenzie \& Berliner (1937) that individual rams differ widely in their susceptibility to seminal degeneration as a result of exposure to high air temperatures. The seminal degeneration observed was correlated with the extent of the rise in the temperature of the subcutaneous scrotal tissue during exposure to high air temperatures, and was not related to rectal temperatures. The general mechanisms for heat loss were able to lower the body temperatures of two of the Class A rams in the hot-dry climate, although the local mechanisms for heat loss from the scrotum were unable to prevent a large rise in the temperature of the subcutaneous scrotal tissue. Since this 
temperature has been shown to correspond closely to the temperature deep within the testis (Waites \& Moule, 1961), it may be concluded that the variation in the seminal degeneration shown by individual rams was due to different thermal loads on the testes. This conclusion is supported by the second experiment in which seminal degeneration of rams in a hot atmosphere was prevented by cooling the scrotum, an observation which has also been made on the bull (Okamoto, Ishii \& Makai, 1959).

The conclusions arising from the present investigations do not necessarily apply to the effects of exposure to high air temperature for longer periods. Depressed thyroid activity has been implicated as a factor in the deranged spermatogenesis of 'summer sterility' in rams (Bogart \& Mayer, 1946; Griffin, Henneman \& Reineke, 1962). The experiments reported here were conducted during the winter expressly to avoid 'summer sterility' and therefore the

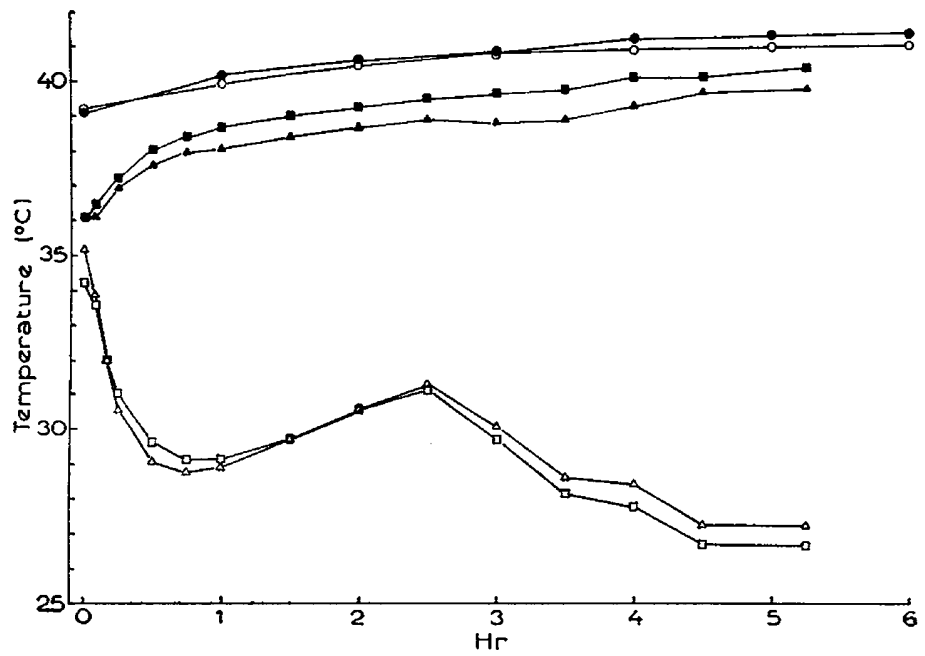

TExr-FIG. 7. The rectal (C), subcutaneous scrotal $(\square \square)$ and testicular $(\Delta \Delta)$ temperatures of two rams in Experiment 2, one without (black symbols) and one with (open symbols) the scrotum cooled. Air temperature $40.5^{\circ} \mathrm{C}, 31.5 \mathrm{~mm} \mathrm{Hg}$ vapour pressure.

endocrine balance of the rams may have differed from that existing during the summer; in addition the periods of exposure to high air temperature were short.

In this study, damaged spermatozoa first appeared in the semen of the Class A rams 13 to 14 days after the experimental treatments, and within 14 to 20 days in the semen of the other rams. It is probable that more severe damage occurred during the second period in the climate room when humid conditions prevailed and when scrotal temperatures rose to higher levels. This means that, when coupled with the occurrence of 3 days between collections, the changes in semen characters noted on Days 13 and 14 may have reflected the effects of events occurring during the previous 10 to 11 days. Should this be so, the indications of seminal degeneration seen on Days 13 and 14 may have resulted from damage to epididymal spermatozoa, since Dawson (1958) showed, and Ortavant (1959) agreed that spermatozoa may take up to 14 days to pass through the epididymis in the ram. The severity of the degeneration 
experienced by the Class A rams between Days 14 and 21 suggests that spermatozoa in the lumen of the seminiferous tubules are readily damaged by the occurrence of high temperatures. The duration and extent of the subsequent seminal degeneration experienced by all rams of Classes A and B indicate profound derangement of earlier stages of spermatogenesis as well. In Class A rams, decreases in the concentration of spermatozoa were most apparent between the 21 st and 32nd days after exposure to high air temperature (Text-fig. 2(c)). This timing, coupled with that of changes in motility and of percentages of dead and abnormal spermatozoa suggests that the further development of some spermatids, and of diplotene and pachytene spermatocytes (Ortavant, 1959) is adversely affected by high testicular temperatures. Since the concentration of spermatozoa did not reach pretreatment levels within 60 days, there is also a suggestion that the earliest stages of cell division in the spermatogenic cycle may have been adversely affected by the experimental treatments.

The production of fructose and citric acid by the seminal vesicles of rabbits and bulls was shown to be abolished by castration and restored by administration of testosterone (Mann \& Parsons, 1947; Mann Davies \& Humphrey, 1949). Lindner \& Mann (1960) demonstrated a positive correlation between the level of secretory activity in the seminal vesicles and the testosterone present in the testes of mature bulls. It seems reasonable, therefore, to relate the increases in seminal fructose (Experiment 1) or in seminal volume (Group 1, Experiment 2) in rams following exposure to high air temperatures to a corresponding increase in the secretion of testosterone. This was also suggested by Glover $(1955,1956)$ who observed similar rises in the concentration of the seminal fructose of rams following insulation of the scrotum which, as here, occurred concurrently with the sperm changes. The effect was not part of a seasonal trend as the concentration of seminal fructose of rams is normally decreasing at the time when the experiments reported here were being done (G. R. Moule and A. W. H. Braden, unpublished observations). A delay of about 2 weeks occurred between the end of the exposure to high air temperature and the beginning of the rise in seminal fructose. A similar delay was observed by Glover (1956) and Clegg (1960) who reported an increase in weight, citric acid and fructose content of the accessory glands of rats 15 days after the operation to make them cryptorchid. The reason for this apparently constant interval between applying heat to either the whole animal or to the testis alone and the rise in seminal fructose is unknown.

Results previously reported by Waites \& Moule (1961) indicated the importance of evaporative cooling from the scrotum in preserving testicular temperatures within their normal physiological range. The present results suggest that the degree of seminal degeneration experienced by individual rams during exposure to high air temperature for short periods is likely to vary with conditions that affect the loss of water from the scrotal skin. Evidence that the apocrine sweat glands of the scrotum of Merino rams are particularly large and active has recently been presented (Waites \& Voglmayr, 1962). It is also interesting to note that testicular temperatures lower than those found in a thermo-neutral environment did not affect semen quality. This is in keeping with the findings of Chang (1943), McDonald \& Harrison (1954) and Harris \& 
Harrison (1955), who showed that the intact scrotum affords protection against low temperatures, although those used in the experiments reported here were not low enough to produce ischaemia.

\section{ACKNOWLEDGMENTS}

We wish to thank Dr R. B. Dun of the Trangie Agricultural Experiment Station, Department of Agriculture, N.S.W., for the rams used in these experiments and Mr P. E. Mattner, Mr J. K. Voglmayr and Mrs Y. Miller for their assistance during the experiments. We are particularly grateful to Dr H. R. Lindner for helpful discussions.

\section{REFERENCES}

Anderson, J. (1945) The semen of animals and its use for artificial insemination. Tech. Commun. Bur. Anim. Br., Edinb., p. 11.

Blackshaw, A. W. (1954) A bipolar rectal electrode for the production of ejaculation in sheep. Aust. vet. 7. 30, 249.

BOgART, R. \& MAYER, D. T. (1946) Environmental temperature and thyroid gland involvement in lowered fertility of rams. Res. Bull. Mo. agric. Exp. Sta., No. 402, p. 25.

Chang, M. C. (1943) Disintegration of epididymal sperm by application of ice to the scrotal testes. 7. exp. Biol. 20, 16.

Clegg, E. J. (1960) Some effects of artificial cryptorchidism on the accessory reproductive organs of the rat. 7. Endocrin. 20, 210.

Comstock, R. E., Green, W. W., Winters, L. M. \& Nordskog, A. W. (1943) Studies of semen and semen production. Tech. Bull. Minn. agric. Exp. Sta., No. 162, p. 1.

Dawson, R. M. C. (1958) The labelling of ram semen in vivo with radioactive phosphate and $\left[\right.$ carboxy $\left.{ }^{-14} \mathrm{C}\right]$ stearic acid. Biochem. F. 68, 512.

Glover, T. D. (1955) Some effects of scrotal insulation on the semen of rams. Proc. Soc. Study Fertil. 7, 66.

Glover, T. D. (1956) The effect of scrotal insulation and the influence of the breeding season upon fructose concentration in the semen of the ram. F. Endocrin. 13, 235.

Griffin, S. A., Henneman, H. A. \& Reineke, E. P. (1962) The thyroid secretion rate of sheep as related to season, breed, sex and semen quality. Amer. J. vet. Res. 23, 109.

Gunn, R. M. C. (1936) Fertility in sheep. Bull. Coun. sci. industr. Res. Aust., No. 94.

Gunn, R. M. G., Sanders, R. N. \& Granger, W. (1942) Studies in fertility in sheep. 2. Seminal changes affecting fertility in rams. Bull. Coun. sci. industr. Res. Aust., No. 148.

Hancock, J. L. (1952) The morphology of bull spermatozoa. 7. exp. Biol. 29, 445.

Harris, R. \& Harrison, R. G. (1955) The effect of low temperature on the guinea-pig testis. Proc. Soc. Study Fertil. 7, 23.

Lindner, H. R. \& MANN, T. (1960) Relationship between the content of androgenic steroids in the testes and the secretory activity of the seminal vesicles in the bull. 7. Endocrin. $21,341$.

McDonald, J. \& Harrison, R. G. (1954) Histological appearances in the testis following exposure to low temperatures. Proc. Soc. Study Fertil. 6, 14.

McKenzie, F. \& Berliner, V. (1937) The reproductive capacity of rams. Res. Bull. Mo. agric. Exp. Sta., No. 265 , p. 108.

Mann, T. (1948) Fructose content and fructolysis in semen. Practical application in the evaluation of semen quality. F. agric. Sci. 38, 323.

Mann, T., Davies, D. V. \& Humphrey, G. F. (1949) Fructose and citric acid assay in the secretions of the accessory glands of reproduction as indicator tests of male sex hormone activity. $\mathcal{J}$. Endocrin. 6,75 .

Mann, T. \& Parsons, U. (1947) Effect of testicular hormone on the formation of seminal fructose. Nature, Lond. 160, 294.

Mattner, P. E. \& Voglmayr, J. K. (1962) A comparison of ram semen collected by the artificial vagina and by electro-ejaculation. Aust. 7. exp. Agric. Anim. Husb. 2, 78.

Moore, G. R. \& OsLund, R. (1924) Experiments on the sheep testis-cryptorchidism, vasectomy and scrotal insulation. Amer. 7. Physiol. 67, 595.

Moule, G. R. \& KNAPp, B. (1950) Ohservations on intratesticular temperatures of Merino rams. Aust. 7. agric. Res. 1, 456. 
Oкамото, S., Ishi, S. \& MukaI, A. (1959) Effect of scrotum cooling on the quality of the seminal fluid of the bull at high temperatures. Fap. F. Anim. Reprod. 5, 22.

Ortavant, R. (1959) Spermatogenesis and morphology of the spermatozoa. Reproduction in Domestic Animals, p. 1. Ed. H. H. Cole and P. T. Cupps. Academic Press, New York.

Wattes, G. M. H. \& Moule, G. R. (1961) Relation of vascular heat exchange to temperature regulation in the testis of the ram. J. Reprod. Fertil. 2, 213.

Waites, G. M. H. \& Voglmayr, J. K. (1962) The apocrine sweat glands of the scrotum of the ram. Nature, Lond. 196, 965. 